\title{
S5ynthesis
}

International Scientific Conference of IT and Business-Related Research

\section{ENERGY AT THE CROSSROADS}

\author{
ENERGIJA NA RASKRŠĆU
}

\author{
Miroslav Trifunović \\ Singidunum University, 32 Danijelova St., Belgrade, Serbia
}

\begin{abstract}
:
Issues related to energy production and consumption are becoming increasingly relevant for the overall economic development and social well-being. There is an almost linear correlation between energy consumption and economy growth. On the other hand, increased energy consumption has adverse effects on the environment, including the presumed influence on climate change. Political aspects of energy resources should not be neglected too, as insignificant number of countries owns most of the non-renewable energy resources. However, the greatest issue related to energy consumption is quite simple: there isn't sufficient amount of energy resources that could meet the needs and aspirations of the growing global population. This paper provides a quantitative overview of the key issues related to global energy consumption and available energy sources with the aim to draw attention to looming issues related to sustainable development.
\end{abstract}

\section{Key words:}

energy consumption, energy resources, energy scarcity.

\section{INTRODUCTION}

Although it has been recognized for many decades that the main energy sources are finite, the substantial discussions about energy sources and energy consumption were actually triggered by assumptions that the use of fossil fuels has a significant negative impact on the environment. In particular, the relationship between $\mathrm{CO}_{2}$ in the atmosphere and global warming has put fossil fuels combustion under thorough scrutiny of climatologists, industries, NGOs and governments. In this paper, the debate about quantitative influence of $\mathrm{CO}_{2}$ on perceived climate changes will be set aside. The author believes that the issues of energy deficiency, in the light of the ever-increasing demand, have to take precedence in the deliberations about the current and future energy use.

\section{ENERGY CONSUMPTION AND ECONOMIC DEVELOPMENT}

The real race between energy needs and discovery of new resources and related technologies started with the industrial revolution. After intensive use of the renewable biomass that covered most of the needs until the second half of the $18^{\text {th }}$ century, industrial revolution produced a quantum leap in energy demand. Fortunately, such spike in demand was matched with the discoveries of coal that greatly contributed to fulfilling of

\section{Apstrakt:}

Problemi vezani za proizvodnju i potrošnju energije su od sve većeg značaja za ekonomski razvoj i društveno blagostanje. Postoji gotovo linearna korelacija između potrošnje energije i ekonomskog rasta. Sa druge strane, povećana energetska potrošnja utiče negativno na životno okruženje, uključujući i navodni uticaj na klimatske promene. Ni politički aspekti vezani za energetske resurse ne mogu biti zanemareni, $s$ obzirom da mali broj zemalja poseduje većinu ne-obnovljivih resursa. Pored svega, najveći problem vezan za potrošnju energije je veoma jednostavan: nema dovoljno energetskih resursa koji su potrebni kako bi se zadovoljile potrebe i očekivanja rastuće globalne populacije. Ovaj rad daje kvatitativni prikaz problema vezanih za globalnu potrošnju energije i raspoložive energetske izvore, sa ciljem da ukaže na dolazeće probleme vezane za održivi razvoj.

\section{Ključne reči:}

potrošnja energije, energetski resursi, insuficijencija energije.

the energy needs. Continuous growth of demand was based on the increased energy consumption per capita, as well as on the exponential growth of the global population. It is not difficult to prove correlation and causal relationship between energy consumption and economic development. Fig. 1 shows the relationship between the power consumption per capita and gross domestic product per capita for the countries around the world (MacKay, 2009). It is obvious that more developed countries use more energy per capita than the non-developed ones. The disparity between the developed and non-developed countries in both measures is huge; rich and developed countries rank 50 times higher than the poorest ones. It has to be noted that the countries on the lower levels of the economic development have legitimate aspirations to improve their well-being and increase of GDP per capita that will come through substantial increase of the individual energy consumption. Such desire is one of the key drivers of increase in total global energy needs.

The second driver of exponential increase in energy consumption is global population growth. The rate of growth is not the same in all countries, and it is typically higher in the countries that are on the lower level of economic development. Over the last 150 years, the global population has increased sevenfold, from 1 billion to over 7 billion. These trends are worrying as they do not show any signs of abating or saturation. Uncontrollable increase of the global population results in strain on primary global resources such as water and food, as well as other finite and non-renewable mineral resources. Fig. 2 shows the 


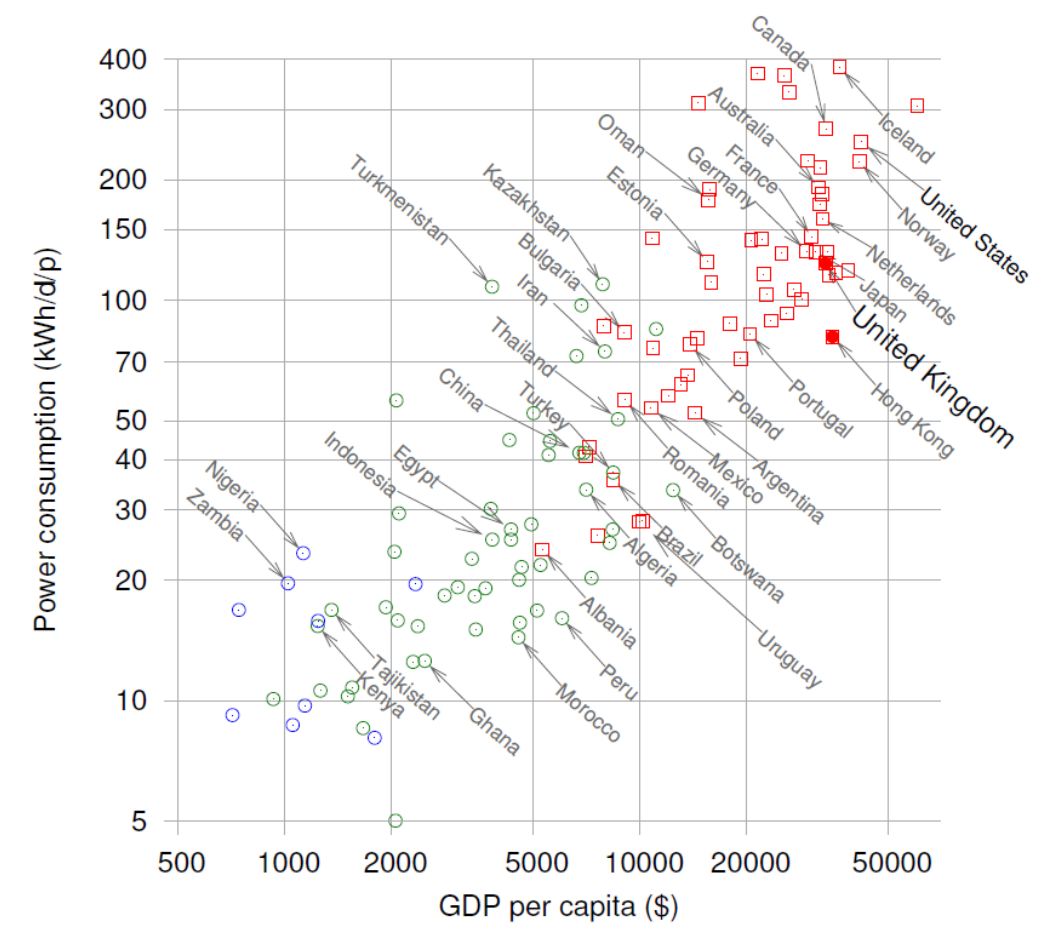

Figure 1. Power consumption per capita vs. GDP per capita

Source: http://www.withouthotair.com/c30/page_231.shtml

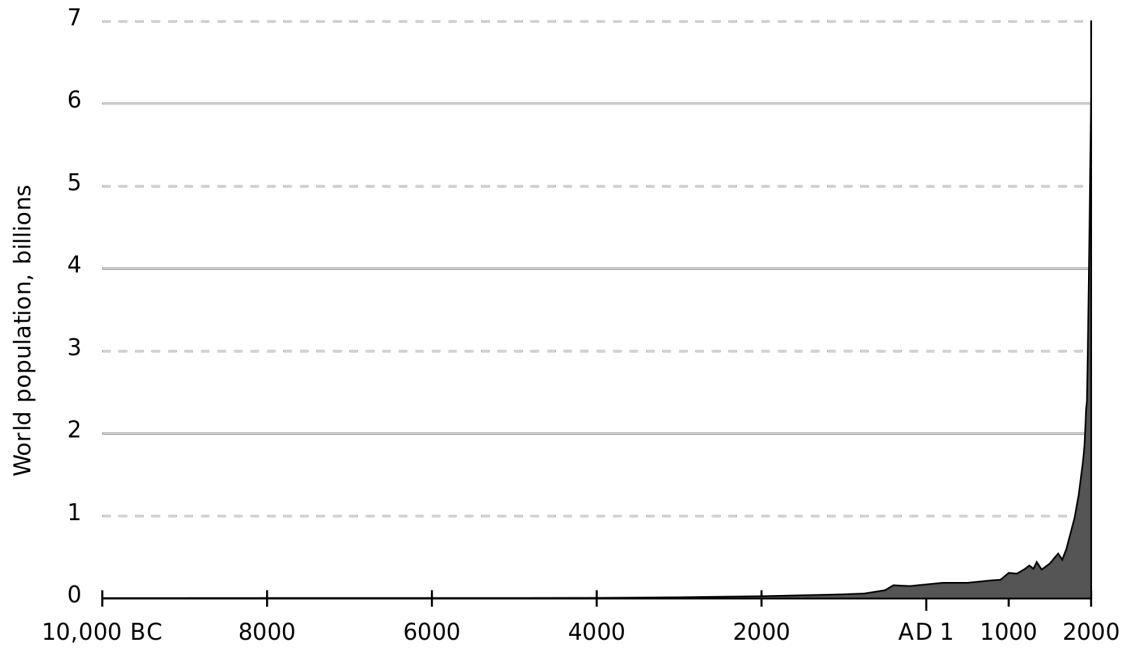

Figure 2. History of world population growth

Source: http://en.wikipedia.org/wiki/File:Population_curve.svg

history of the global population growth, which clearly indicates that renewable energy sources (mainly wood) were sufficient for the human survival until the middle of the second millennium.

Historically, along with the growing energy demand, science and technology were coming with credible energy responses that could cater for the new needs. Coal in $18^{\text {th }}$ and $19^{\text {th }}$ century and petroleum and nuclear in $20^{\text {th }}$ century were the key enablers of economic growth. It is necessary to point out that today there are no new energy sources of the same magnitude, ready for exploitation.

The compounding effects of the population growth and growth of consumption per capita have resulted in today's energy consumption of $150.000 \mathrm{TWh}$, which is several orders of magnitude higher than the consumption form in the not-sodistant past. As Fig. 3 shows, only in the period 1990-2010, the global energy consumption increased by over $50 \%$. It should be noted that in 1992, almost 200 countries have signed up to a
Kyoto Protocol, committing to reduce and minimize $\mathrm{CO}_{2}$ emissions. Nevertheless, most of the $50 \%$ of the energy consumption increase during the mentioned period is to be attributed to the fossil fuels that are responsible for the anthropogenic $\mathrm{CO}_{2}$ emissions.

During the same period, the global population increased by over $25 \%$. In the developed countries, the population growth is moderate or around zero and the overall energy consumption is also stable. The most of the energy consumption challenges are coming from the developing countries, both because of their strong population growth and their low level economies. Considering the overall global needs and legitimate aspirations for better life, it is obvious that the existing energy resources will be under tremendous pressure and that the competition for energy sources will be severe. In such a situation, it is prudent to make even a rough estimate on how much energy is necessary to satisfy reasonable human needs. 


\begin{tabular}{|c|c|c|c|c|c|c|c|c|c|c|c|}
\hline \multirow[b]{3}{*}{ Region/Country } & \multirow{2}{*}{\multicolumn{4}{|c|}{ Energy Consumption (TWh) }} & \multirow{2}{*}{\multicolumn{3}{|c|}{ Population (million) }} & \multicolumn{4}{|c|}{ Annual Growth Rate } \\
\hline & & & & & & & & \multicolumn{2}{|c|}{$1990-2000$} & \multicolumn{2}{|c|}{$2000-2010$} \\
\hline & $\underline{1990}$ & $\underline{2000}$ & $\underline{2010}$ & & $\underline{1990}$ & 2000 & $\quad \underline{2010}$ & Energy & Pop. & Energy & Pop. \\
\hline United States & 24924 & 29257 & 28664 & $18,7 \%$ & 250 & 282 & $311 \quad 4,6 \%$ & $1,6 \%$ & $1,2 \%$ & $-0,2 \%$ & $1,0 \%$ \\
\hline China & 7913 & 10654 & 30656 & $20,0 \%$ & 1.148 & 1.264 & $1.34320,0 \%$ & $3,0 \%$ & $1,0 \%$ & $11,1 \%$ & $0,6 \%$ \\
\hline OECD Europe & 20495 & 22514 & 23329 & $15,2 \%$ & 402 & 522 & $550 \quad 8,2 \%$ & $0,9 \%$ & $2,6 \%$ & $0,4 \%$ & $0,5 \%$ \\
\hline Other Non-OECD Asia & 3671 & 6050 & 9173 & $6,0 \%$ & 781 & 1.014 & t $1.08616,2 \%$ & $5,1 \%$ & $2,6 \%$ & $4,2 \%$ & $0,7 \%$ \\
\hline Russia (1) & 17871 & 7977 & 8763 & $5,7 \%$ & 288 & 147 & $7 \quad 140 \quad 2,1 \%$ & $-7,7 \%$ & $-6,5 \%$ & $0,9 \%$ & $-0,5 \%$ \\
\hline Central \& S. America & 4247 & 6099 & 8236 & $5,4 \%$ & 359 & 422 & $6,9 \%$ & $3,7 \%$ & $1,6 \%$ & $3,0 \%$ & $0,9 \%$ \\
\hline Middle East & 3288 & 5083 & 8089 & $5,3 \%$ & 135 & 173 & $3,2 \%$ & $4,5 \%$ & $2,5 \%$ & $4,8 \%$ & $2,1 \%$ \\
\hline Japan & 5504 & 6576 & 6096 & $4,0 \%$ & 124 & 127 & $1,9 \%$ & $1,8 \%$ & $0,3 \%$ & $-0,8 \%$ & $0,0 \%$ \\
\hline India & 2309 & 3945 & 6975 & $4,6 \%$ & 838 & 1.006 & $1.21418,1 \%$ & $5,5 \%$ & $1,8 \%$ & $5,9 \%$ & $1,9 \%$ \\
\hline Canada & 3218 & 3828 & 4191 & $2,7 \%$ & 28 & 31 & $134 \quad 0,5 \%$ & $1,8 \%$ & $1,1 \%$ & $0,9 \%$ & $0,9 \%$ \\
\hline Oth. Non-OECD Europe & 1867 & 5152 & 5686 & $3,7 \%$ & 154 & 128 & $3,0 \%$ & $10,7 \%$ & $-1,8 \%$ & $1,0 \%$ & $4,5 \%$ \\
\hline Africa & 2775 & 3527 & 5715 & $3,7 \%$ & 631 & 804 & t $1.00114,9 \%$ & $2,4 \%$ & $2,4 \%$ & $4,9 \%$ & $2,2 \%$ \\
\hline South Korea & 1126 & 2298 & 2989 & $2,0 \%$ & 43 & 47 & $790,7 \%$ & $7,4 \%$ & $0,9 \%$ & $2,7 \%$ & $0,5 \%$ \\
\hline Mexico/Chile (2) & 1379 & 1870 & 2491 & $1,6 \%$ & 85 & 100 & $1,9 \%$ & $3,1 \%$ & $1,6 \%$ & $2,9 \%$ & $2,5 \%$ \\
\hline Australia \& N. Zealand & 1301 & 1665 & 2022 & $1,3 \%$ & 20 & 23 & $0,4 \%$ & $2,5 \%$ & $1,2 \%$ & $2,0 \%$ & $1,3 \%$ \\
\hline Total World & 101887 & 116495 & 153077 & $100 \%$ & 5.287 & 6.089 & $6.701100 \%$ & $1,3 \%$ & $1,4 \%$ & $2,8 \%$ & $1,0 \%$ \\
\hline \multicolumn{12}{|c|}{ Note(s): 1) 1990 Values for Russia approximated by Former USSR. 2) Before 2010, Mexico/Chile category only included Mexico. } \\
\hline \multicolumn{12}{|c|}{ Source(s): EIA, International Energy Outlook 2011, Sept. 2011, Table A1, p.157; EIA, Country Profiles http://www.eia.gov/country/index.cfm } \\
\hline
\end{tabular}

Figure 3. Energy consumption and population growth, 1990-2010

\section{GLOBAL ENERGY DEMAND ESTIMATE}

It is difficult to make a firm estimate of global energy demand for a variety of reasons. The overall population growth, different levels of current energy consumption and influence of politics on energy availability are the main hurdles that prevent exact needs estimate. At this stage, it is also necessary to distinguish between needs and aspirations. Even though the basic needs can be rather small, the natural aspiration for a specific lifestyle (which is directly related to the energy consumption) is something completely different. The ever-increasing population growth was already illustrated and analyzed in the previous chapter. The growth in global energy demand is even steeper, as it is compounded by the fact that the energy consumption per capita is increasing as well.

The analysis has been carried out for countries and regions of the world, taking into account the local average energy consumption per capita. The results are presented in Fig. 4.

Each small segment on the horizontal axes represents 30 million people; the vertical axis presents the average energy consumption per capita per person, in $\mathrm{MWH} /$ person/year. It is clear that the developed parts of the world are using much more energy per capita than the rest of the world. It is equally clear that those countries with large population (China and India) or other regions (Africa, non-OECD countries) show ambitions to develop their economies and drastically increase their average energy consumption per capita. In order to provide the global population with the same level of energy per capita consumption as it is currently in the USA, global energy production and consumption would need to be roughly six times higher than today. This estimate is made under the assumption that the average consumption per capita in the referent country (USA) will not grow further. Another assumption made in this analysis is that the global population will saturate on around 7 billion, which is not very likely. It is expected that the global population will have grown for 2.3 billion by 2050 , which equals roughly today's population of China and India. This means that factor six is rather conservative, even if serious energy savings are put in place. Apparently, some of the studies conducted at Stanford University argue that optimal population on the Earth

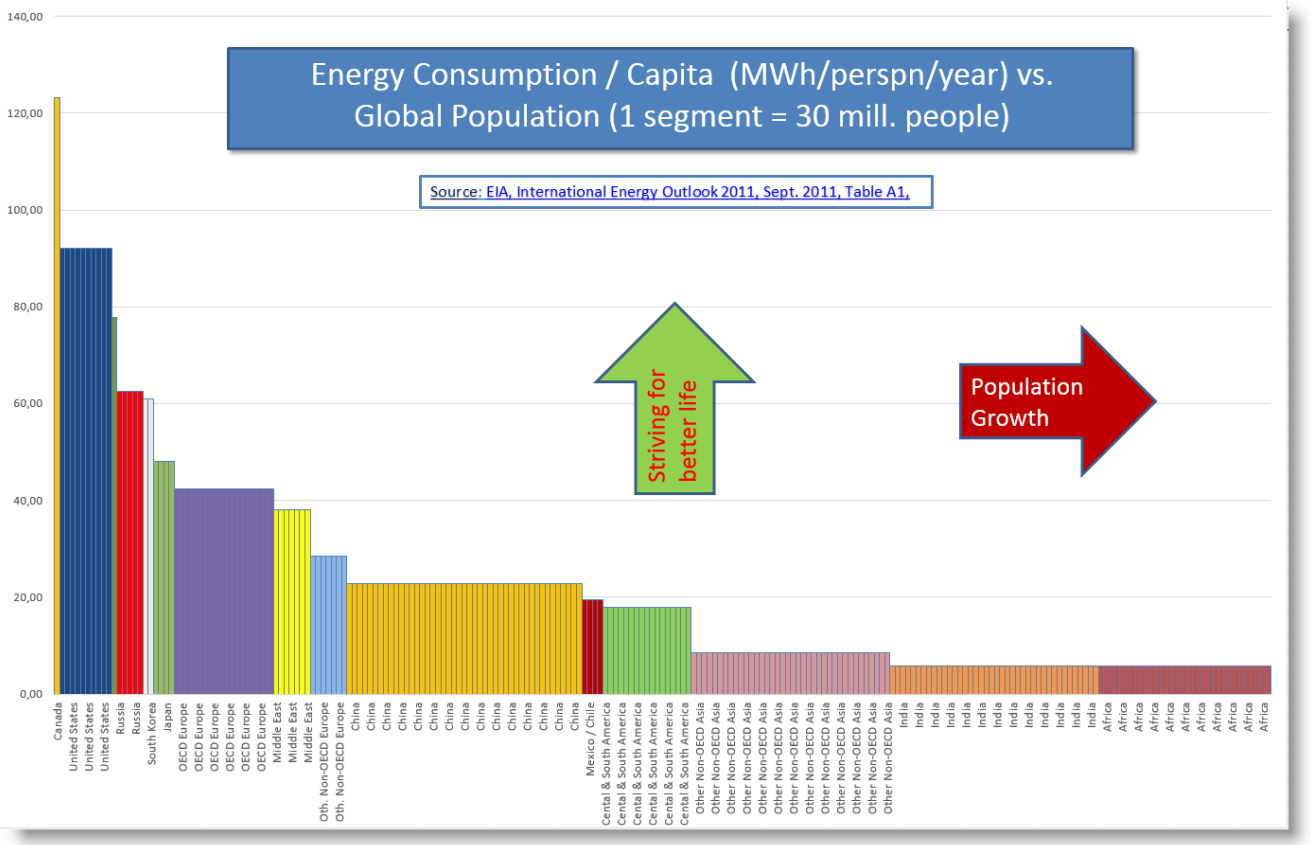

Figure 4. Energy consumption per capita

Source: International Energy Outlook 2011, September 2001, Table 1 
would number around 1.5-2 billion people (Daily et al., 1994). Although pertinent to this paper, the discussion on this specific topic is not subject of this paper. Nevertheless, it confirms that with the current state of energy technology, today's energy consumption is only $1 / 6$ of the estimated aspiration of today's population.

\section{CURRENT GLOBAL ENERGY PRODUCTION}

The current total energy production is being estimated by many reputable organizations and institutions. One of the most quoted sources is Lawrence Livermore National Laboratory in California (USA), whose energy flow is very helpful to understand the supply part of the energy equation (Smith et al., 2011).

The global picture of energy flows shows the overall status of primary and secondary energy sources and their main consumption sectors. The primary source split shown on the left side confirms that renewable sources play a minor role in the total energy mix. Fossil fuels and uranium constitute almost $88 \%$ of total consumption, although there has been an intensive debate aiming to replace a larger part of fossil fuels with renewable energy sources over the past two decades.

Even within renewable sources, the "traditional" ones (hydro and biomass) compromise a large majority: $95 \%$ of total renewable sources. In 2007, solar, wind, geothermal and other renewable sources made up only $5 \%$ or $0.6 \%$ of the total primary energy use worldwide.

In the last eight years, the use of "non-traditional" renewable sources has increased globally and at an impressive rate, particularly in developed countries. In the USA, they quadrupled, accounting for $23 \%$ of all renewable sources. However, in the total current USA energy balance, they represent just above $2 \%$ of the total primary energy consumption, which includes both renewable and non-renewable energy sources.

As can be seen in the figure, almost $40 \%$ of all primary energy sources are used to produce electricity and heat, as those are the most convenient forms of energy for practical use.
Energy is used primarily in three sectors: around 29\% for buildings, $40 \%$ for industries and $22 \%$ for transportation. These data have approximate values; different sources might give different global percentages. Nevertheless, these three sectors are dominant and require individual attention for a more detailed analysis.

Finally, the data on the right side of the chart show that more than half of the energy used from the primary sources is lost as "rejected energy". Improving the efficiency of the energy usage could reduce such energy waste in all three sectors. However, such reductions can improve the situation only to a certain degree. At the current level of technology, it is practically impossible to substantially reduce the rejected energy related to the electricity production or use in one of the mentioned sectors.

Individual countries would have rather different values in their energy flow charts, depending on their economies and the availability of indigenous primary energy sources.

\section{ENERGY RESOURCES}

Global non-renewable energy resources are finite. They have been intensively used from the beginning of the $20^{\text {th }}$ century and are being rapidly depleted. The new major discoveries are rather rare, fuels are of lower quality and more difficult to extract and refine. According to some energy analysts, the peak oil point (the point of the maximum global oil production) is happening just now and the production will gradually decline in the near future. Similar scenarios are expected for coal and gas.

Another important fact is that non-renewable resources are owned by the countries if they are found on their sovereign territories. Most of the global oil and gas reserves are found only in three regions: Middle East, Russia and the USA. Only five countries (USA, Russia, China, Australia and India) owe 65\% of all global coal reserves. Today, the countries trade their surpluses, but there is a realistic scenario that energy resources will be used as means for political or economic pressure.

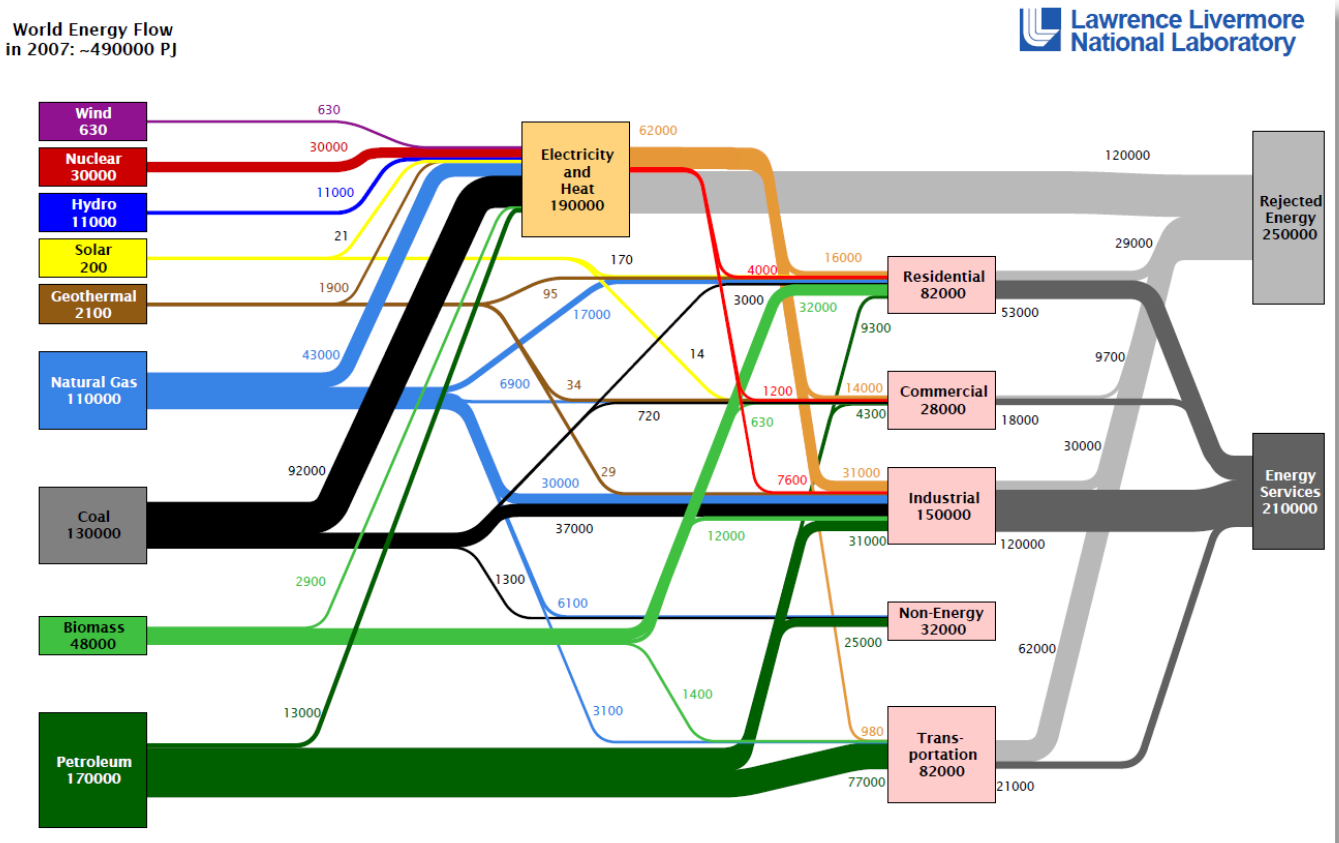


On the other hand, although renewable energy sources are inexhaustible, quantitatively, they cannot simply replace the current non-renewable sources. They have a problem of intermittency, geographical distribution and absolute energy quantity available on a daily basis. In addition, there are issues of the investment levels needed, raw materials and ERoEI evaluations.

\section{RESULTS AND DISCUSSION}

Considering the global energy issues, it is clear that the outlook is not too promising. Energy deficiency was not a topic some 120 years ago. However, the fact is that $50 \%$ of all estimated non-renewable sources have been used over the last 120 years. It took hundreds of millions of years for these fuels to be formed in the Earth core. Currently, there is no technology that could replace oil, gas and coal, even on the current level of energy consumption.

In the $21^{\text {st }}$ century, the world will have to make serious efforts in several directions: improvement of energy efficiency wherever possible, deployment of the renewable energy resources where economically viable, development of completely new, currently unknown energy technologies and better management of the overall population growth.

\section{REFERENCES}

MacKay, D. (2009). Sustainable Energy: Without the Hot Air. Retrieved from http://www.withouthotair.com

MacKay, D. (2007). 30 Energy plans for Europe, America, and the World. Retrieved from http://www.withouthotair.com/ c30/page_231.shtml

Smith, C.A., Belles, R.D., \&. Simon, A.J. (2011). 2007 Estimated International Energy Flows. Retrieved from https://e-reports-ext.llnl.gov/pdf/473335.pdf

Gretchen, C., Daily, A., Ehrlich, H., \& Ehrlich, P.R. (1994). Optimum Human Population Size. Population and Environment. A Journal of Interdisciplinary Studies, 15 (601994). Retrieved from http://dieoff.org/page99.htm 